\title{
スプレー熱分解法による有灣スズ化合物 からの酸化スズ膜の成長
}

\author{
八木 績・福島 正一*・井本 文夫*·金子 正治* \\ (株)河合楽器製作所 T430 浜松市寺島町 200 \\ * 静岡大学工学部材料精密化学科 $\mathbf{T} 432$ 浜松市城北 3-5-1
}

(1991年 3 月 11 日 受理)

\section{Growth of $\mathrm{SnO}_{2}$ Thin Films from Organotin Compounds by Spray Pyrolysis}

\author{
Isao YAGI, Shoichi FUKUSHIMA*, Fumio IMOTO* and Shoji KANEKO* \\ KAWAI Co., Ltd., \\ 200, Terajima, Hamamatsu 430 \\ * Department of Materials Science and Technology, Shizuoka University \\ 3-5-1, Jouhoku, Hamamatsu 432
}

(Received March 11, 1991) (Accepted May 13, 1991)

\begin{abstract}
Growth of tin oxide films on glass substrates from the solution of several organotin compounds, $\left(\mathrm{C}_{4} \mathrm{H}_{9}\right)_{4} \mathrm{Sn},\left(\mathrm{C}_{4} \mathrm{H}_{9}\right)_{3} \mathrm{SnOOCCH}{ }_{3},\left(\mathrm{C}_{4} \mathrm{H}_{9}\right)_{2} \mathrm{Sn}\left(\mathrm{OOCCH}_{3}\right)_{2},\left(\mathrm{C}_{4} \mathrm{H}_{9}\right)_{3} \mathrm{SnCl}$ and $\left(\mathrm{C}_{4} \mathrm{H}_{9}\right)_{2} \mathrm{SnCl}_{2}$, by spray pyrolysis has been found to be possible. Of these compounds, only the crystallinity of the tin oxide film grown from $\left(\mathrm{C}_{4} \mathrm{H}_{9}\right)_{2} \mathrm{SnCl}_{2}$ was affected by annealing at $600^{\circ} \mathrm{C}$ after being prepared at $400^{\circ} \mathrm{C}$. The texture coefficient of the tin oxide films determined from XRD profiles showed that preferred orientation of the films were different depending on the source compounds. The crystallite size of the tin oxide films was also discussed in terms of the growth parameters. Furthermore, it has been proved that the films grown from the Cl-free compounds were of smooth surfaces.
\end{abstract}

\section{1. 緒 言}

酸化スズはバンドキャップが広く易動度の大きい $\mathrm{n}$ 型 の酸素欠陥型半導体であり "), 可視光に対して透明で, 赤外線を反射する。ドーピングにより酸化スズの電気的 および光学的性質を制御するととも可能である。また酸 化スズは化学的に安定であり, 高硬度でああるので, 特 亿薄膜として抵抗体, 透明発熱体, 透明電極, 光学的選 択吸収・帯電防止・耐磨耗性のためのコーティングとし て利用されてきた2”。最近では, ITO 膜と並えで,さら に ECD, EL 素子や太陽電池などの䢪明電極および薄膜 ガスセンサーとしての利用む図られている2)。

スプレー熱分解法は半世紀ほど前から，ガラス容器の 装飾法および耐磨耗用酸化鉄・酸化スズなどのコーティ

$\dagger$ 第 10 回表面科学講演大会 (1990 年 12 月 $3 \sim 5$ 日) 飞て発 表。
ング法として用いられてきた。1951 年には，本手法を用 いてガラスに透明導電膜を形成する方法としても，いく つかの特許が取得された ${ }^{3)}$ 。1966 年に，ての方法によっ て太陽電池用 CdS 膜が作られて以来 ${ }^{4)}$ ，スプレー熱分解 法は装置が簡便でスケールアップが容易であり，膜を大 規模に形成するのに有利な方法であるとして注目され， 貴金属膜, 酸化物膜, カルコゲナイド化合物膜などの形 成が広範囲に検討されてきた ${ }^{5)}$ 。

スプレー熱分解法により，酸化スズ膜を成長させる場 合, その原料にはすっぱら $\mathrm{SnCl}_{4}$ が用いられ，てれ以 外の原料化合物比ついての報告は少なく，その多くは $\mathrm{MA}_{4}$ (Aは単独陰イオンあるいは基および配位子) とい った単純化合物であり, MABC... (A, B, C は単独陰イ オンあるいは基㧍よび配位子) のような数種類の単独陰 イオンあるいは基および配位子からなる化合物を用いた 例はさら飞少ない。 $\mathrm{SnCl}_{4}$ 以外の原料化合物を用いた例 
には $\left.\left.\mathrm{SnCl}_{2}{ }^{5}, \mathrm{SnBr}_{4}^{5}\right),\left(\mathrm{CH}_{3}\right)_{4} \mathrm{Sn},\left(\mathrm{C}_{4} \mathrm{H}_{9}\right)_{4} \mathrm{Sn}^{6}\right),\left(\mathrm{NH}_{4}\right)_{2} \mathrm{Sn}$ $\mathrm{Cl}_{6}^{5},\left(\mathrm{CH}_{3} \mathrm{COO}\right)_{2} \mathrm{SnCl}_{2}{ }^{7},\left(\mathrm{C}_{4} \mathrm{H}_{9}\right)_{2} \mathrm{SnO}^{8,9)}$ などがある。 また, 成長パラメータと酸化スズ膜の電気的・光学的性 質の関係は種々検討されてきたが, 微禮造との関係を詳 細に検討した報告は少なく、いずれも原料化合物には, $\mathrm{SnCl}_{4}$ のみが用いられている10 12)。

そこで著者らは, 中心金属 $\mathrm{Sn}$ への置換基の種類と数 を順次変えた一連の有機スズ化合物 $\left[\left(\mathrm{C}_{4} \mathrm{H}_{9}\right)_{4} \mathrm{Sn},\left(\mathrm{C}_{4} \mathrm{H}_{9}\right)_{3}\right.$ $\mathrm{SnOOCCH}_{3},\left(\mathrm{C}_{4} \mathrm{H}_{9}\right)_{2} \mathrm{Sn}\left(\mathrm{OOCCH}_{3}\right)_{2},\left(\mathrm{C}_{4} \mathrm{H}_{9}\right)_{3} \mathrm{SnCl}$ および $\left(\mathrm{C}_{4} \mathrm{H}_{9}\right)_{2} \mathrm{SnCl}_{2}$ ] を用いて酸化スズ膜を成長させ, 膜の成 長条件と徽構造を検討した。

\section{2. 実 験方法}

\section{1 スブレー原料}

使用した有機スズ化合物を Table 1 に示した。また， 比較のため四塩化スズ, Tin (IV) chloride, anhydrous ( $\mathrm{SnCl}_{4}$ : 以後 TTC と略す, ヨッハ夕化学製 99.5\%) を 使用した。

\section{2 スプレー装置および成長パラメータ}

使用したスプレー装置の概略を Fig. 1 亿示す。有機 スズ化合物または四塩化ススのエチルアルコール溶液 を王縮空気 $\left(1 \mathrm{~kg} / \mathrm{cm}^{2}\right)$ により二流体式スプレーガンを 用いて霧化し， $250 \mathrm{~mm}$ 離れたホットプレート上の基板 $(25 \times 25 \times 1 \mathrm{~mm}$ のコーニング 7059 ガラス) に吹き付 け酸化スズ膜を成長させた。

成長は間欠法により行った。つまり, 1 回の吹き付け により基板温度が $15 \sim 25^{\circ} \mathrm{C}$ 下降するため, 基板温度か 所定の温度に回復してから，再び吹き付けを行うという ととを絽返した。1回の吹き付け時間は1秒とし，その ときの吹き付け量は約 $0.5 \sim 1.5 \mathrm{ml}$ とした。基板温度は 勘板側面に設置したシース型熱電対 $(1.5 \mathrm{~mm} \phi)$ により 測定し，PID コントローラで制御した。基板㳑度は 400 , 450 および $500^{\circ} \mathrm{C}$ とした。スプレー液濃度は, $\mathrm{SnO}_{2}$ に 换算して $2.0 \sim 10 \mathrm{wt} \%$ とし, 溶媒にはすへて乾燥した インプロピルアルコール変性 $(13.6 \%)$ エチルアルコー ルを使用した。

Table 1 Organotin compounds used.

\begin{tabular}{l|l|r|l|l}
\hline \multicolumn{1}{c|}{ Compound } & \multicolumn{1}{c|}{ Manufacturer } & Purity & \multicolumn{1}{|c}{ Chemical formula } & \multicolumn{1}{c}{ Abbr. } \\
\hline Tetra-n-butyltin (IV) & MERCK & $>97 \%$ & $\left(\mathrm{C}_{4} \mathrm{H}_{9}\right)_{4} \mathrm{Sn}$ & TBT \\
Tri-n-butyltin (IV) acetate & MERCK & $96 \%$ & $\left(\mathrm{C}_{4} \mathrm{H}_{9}\right)_{3} \mathrm{SnOOCCH}$ & \multicolumn{1}{l}{ TBTA } \\
Di-n-butyltin (IV) diacetate & NITTO KASEI & $>95 \%$ & $\left(\mathrm{C}_{4} \mathrm{H}_{9}\right)_{2} \mathrm{Sn}(\mathrm{OOCCH})_{2}$ & DBTDA \\
Tri-n-butyltin (IV) chloride & TOKYO KASEI & $95 \%$ & $\left(\mathrm{C}_{4} \mathrm{H}_{9}\right)_{3} \mathrm{SnCl}$ & TBTC \\
Di-n-butyltin (IV) dichloride & MERCK & $98 \%$ & $\left(\mathrm{C}_{4} \mathrm{H}_{9}\right)_{2} \mathrm{SnCl}_{2}$ & DBTDC \\
\hline
\end{tabular}

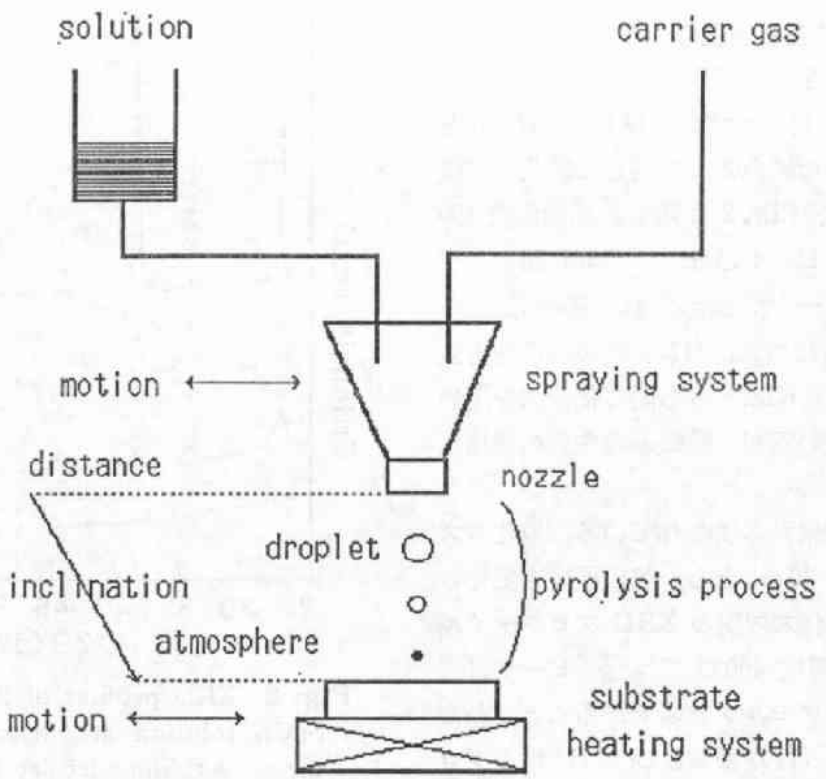

Fig. 1 Schematic diagram of the spray pyrolysis apparatus. 


\section{3 吩棈造の解析}

\subsubsection{X線回折測定および跑向性・結晶子径の評価}

酸化スズ膜のX線回折測定には，島津 XD-610 型X線 回折装置を用い, $\operatorname{CuK} \alpha$ 線を使用した。

成長した酸化スズ膜の配向性を(1)式から求めた組織 係数 (Texture coefficient; TC) により評価した ${ }^{13) 。 ~}$

$$
T C(\mathrm{hkl})=\frac{I(\mathrm{hkl}) / I_{0}(\mathrm{hkl})}{1 / N\left(\sum_{N} I(\mathrm{hkl}) / I_{0}(\mathrm{hkl})\right)}
$$

とこで, TC (hkl) は試料の (hkl) 面の組織係数を表わ L，I(hkl) は試料の (hkl) 面加らの回折X線の測定強度 ( $K \alpha_{1}$ 楾)，I0 (hkl) は粉末試料の (hkl) 面加らの JCPDS 標準強度 $\left(\mathrm{SnO}_{2}\right.$, Cassiterite, Card No. 21-1250), $N$ は 回折線の数 $(N=31)$ を表わしている。つまり, $T C(\mathrm{hkl})$ $=1$ とは成長した膜が (hkl) 面に関して無配向であるて とを澺味する。

また，(2)式により, 酸化スズの結晶子径を求めた (Scherrer の方法) ${ }^{14}$ 。

$$
D_{\mathrm{hkl}}=\frac{K \lambda}{B \cos \theta}
$$

ことで, $D_{\mathrm{hkl}}$ は (hkl) 面に垂直方向の結晶子径, $\theta$ は 回折角度, $\lambda$ はX線の波長 (1.54 $\mathrm{A}), B$ には回折ピーク の半值稫 ( $K \alpha_{1}$ 線) を用い, Scherrer 定数 $K$ は 0.9 と した。

\subsubsection{SEM 観察}

成長した酸化スズ膜の膜表面の形態観察には日本電子 JSM-T300 型走査型電子顕徽鏡を用いた。

\section{3. 結果および考察}

\section{1 膜の成長に及ぼす基板温度の影響}

\subsection{1 $\left(\mathrm{C}_{4} \mathrm{H}_{9}\right)_{4} \mathrm{Sn}$, TBT}

原料化合物に TBT を用いスプレー総量を $67 \mathrm{ml}$ と し, 基板温度を変化させた場合の, 成長した酸化スズ膜 の XRD プロファイルを Fig. 2 亿示す。基板温度 400 'C では (110) 面の回折ピークのほか, (200) 面および (211) 面の微弱な回折ピークが認められ, 基板温度が $450^{\circ} \mathrm{C}, 500^{\circ} \mathrm{C}$ と上昇するにつれ，(110) 面のみの回折強 度が徐々に増加している。 $\mathrm{Kim}^{6)}$ らす同じ化合物を用い て酸化スズ膜を作製しているが, 成長過程や膜の微構造 の詳細は明らかでない。

一方, 原料化合物飞従来加ら使われている四塩化スズ を用い, スプレー総量を $40 \mathrm{ml}$ とし，基板温度を変化さ せた場合の, 成長した酸化スズ膜の XRD プロファイル を Fig. 3 に示す。基板温度 $400^{\circ} \mathrm{C}$ では回折ピークは認 められず, 酸化スズ膜はアモルファスであることがわか る。基板温度 $450^{\circ} \mathrm{C}$ では (110) 面および (211) 面のブロ ードな回折ピークと (101) 面および (200) 面の明瞭な回
折ピークが認められる。基板温度 $500^{\circ} \mathrm{C}$ では (110) 面の 回折ピークは強度も増加しシャープとなったが，(200) 面の回折強度は著しく増加し，(200）面の優先的配向が 起とっていると考えられる。一方，(101）面の回折ピー クはほとんど消失している。また，弱い(301) 面とかな り強い(310) 面の回折ピークも現れている。

スプレー熱分解法で原料化合物に TTC あるいはその 水和物を用いた場合, 最強回折ピークが $(110)$ 面 ${ }^{15)}$,

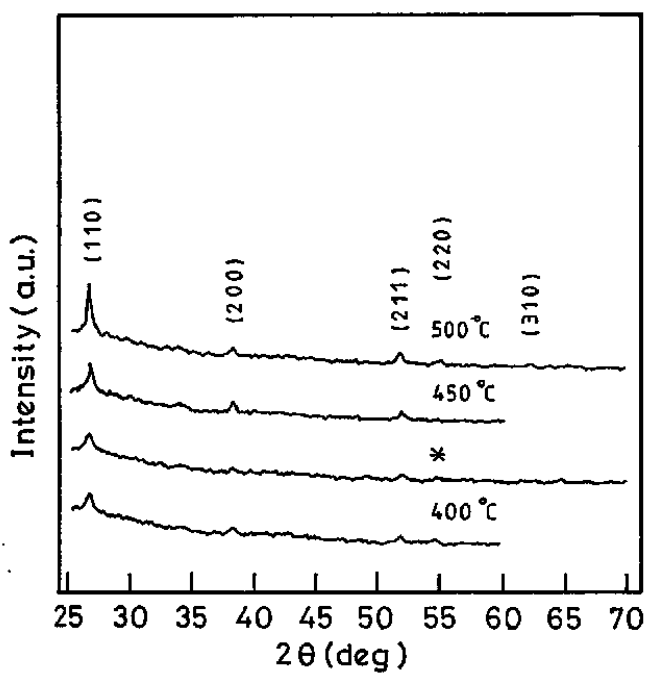

Fig. 2 XRD profiles of $\mathrm{SnO}_{2}$ films grown from $\left(\mathrm{C}_{4} \mathrm{H}_{9}\right)_{4} \mathrm{Sn}$ solution at various substrate temperatures. *: Annealed at $600^{\circ} \mathrm{C}$ after prepared at $400^{\circ} \mathrm{C}$.

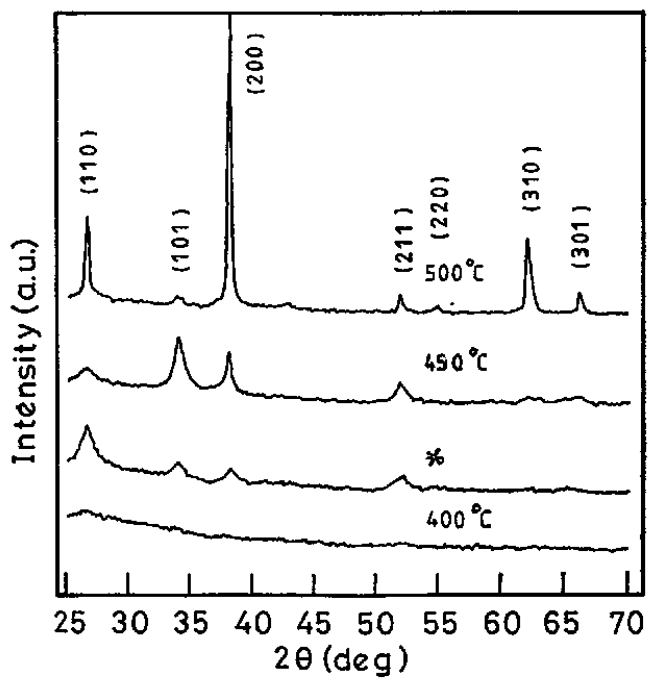

Fig. $3 \mathrm{XRD}$ profiles of $\mathrm{SnO}_{2}$ films grown from $\mathrm{SnCl}_{4}$ solution at various substrate temperatures. *: Annealed at $600^{\circ} \mathrm{C}$ after prepared at $400^{\circ} \mathrm{C}$. 
(101) 面 ${ }^{16)}$ ，(200）面10-12,15-20)，(211) 面占) あるいは (002) 面 ${ }^{12)}$ 之さまざまに変化するととが報告されている が，乙のうち (200) 面および (002) 面が示す配向性が高 いとされ，またとてでのアモルファスから多結晶体への 転移基板温度についても $240^{\circ} \mathrm{C}^{18)}, 320^{\circ} \mathrm{C}^{15)}$ あるいは $350^{\circ} \mathrm{C}^{19,21)}$ とのさまざまな報告がある。しかし，との違 いは主としてスプレー液濃度および供給速度の差が原因 であると考えられる。著者らあまた，スプレ一液濃度を 低くするか，あるいは供給速度を遅くして，より低い温 度で (200) 面の強い回折ピークを得ている。

とのように，四塩化スズばかりでなく TBT のような 有機スズ化合物を用いても酸化スズ膜を形成するとと ができ，その配向性は四塩化スズと異なるととがわかっ た。

\subsection{2 $\left(\mathrm{C}_{4} \mathrm{H}_{9}\right)_{3} \mathrm{SnOOCCH}_{3}$, TBTA およひ $\left(\mathrm{C}_{4} \mathrm{H}_{9}\right)_{2} \mathrm{Sn}\left(\mathrm{OOCCH}_{3}\right)_{2}$, DBTDA}

TBT のブテル基をアセトキシ基に置换した有機スズ 化合物, TBTA を用いてスプレー総量を $40 \mathrm{ml}$ とし, 基板温度を変化させた場合の，成長した酸化スズ膜の XRD プロファイルを Fig. 4 亿示す。基板温度 $400^{\circ} \mathrm{C}$ では (110) 面の弱い回折ピークおよび (200) 面と (211) 面の微弱な回折ピークが認められ，TBT の場合とほほ 同様である。基板温度 $450^{\circ} \mathrm{C}$ では TBT と異なり,(110) 面ではなく (200) 面と (211) 面の回折強度が堌大しはっ きりと認められ，新たに (101) 面と (301) 面の回折ピー クの存在も確認できる。基板温度 $500^{\circ} \mathrm{C}$ ではすべての回 折強度は増加傾向にあるが, TBT と異なって (110) 面

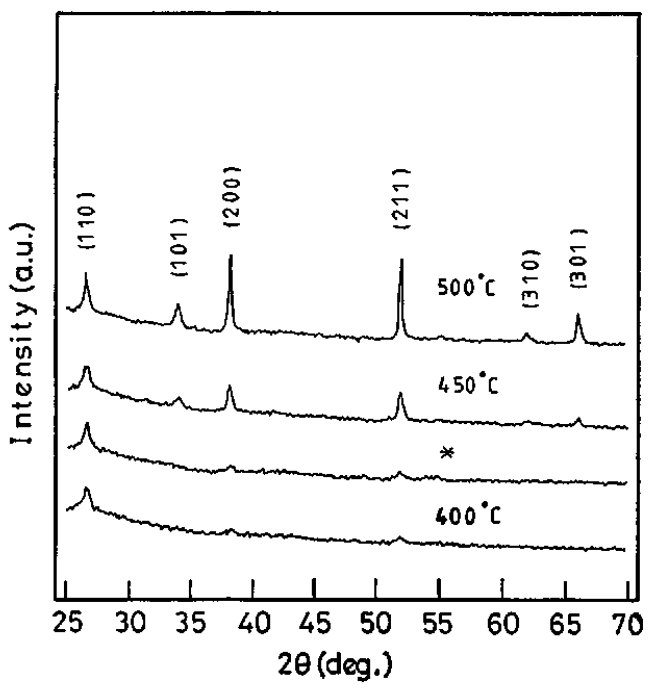

Fig. 4 XRD profiles of $\mathrm{SnO}_{2}$ films grown from $\left(\mathrm{C}_{4} \mathrm{H}_{9}\right)_{3} \mathrm{SnOOCCH}_{3}$ solution at various substrate temperatures. * : Annealed at $600^{\circ} \mathrm{C}$ after prepared at $400^{\circ} \mathrm{C}$.

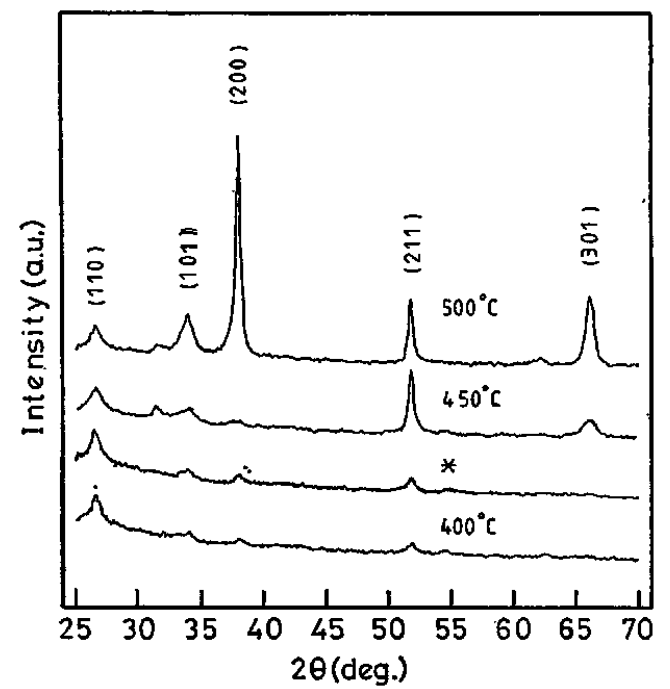

Fig. 5 XRD profiles of $\mathrm{SnO}_{2}$ films grown from $\left(\mathrm{C}_{4} \mathrm{H}_{9}\right)_{2} \mathrm{Sn}\left(\mathrm{OOCCH}_{3}\right)_{2}$ solution at various substrate temperatures. *: Annealed at $600^{\circ} \mathrm{C}$ after prepared at $400^{\circ} \mathrm{C}$.

よりむしろ，(101）面，(301）面,特に (200) 面之 (211) 面の回折ピーク強度が大きく堌加している。

一方，原料化合物に DBTDA を用いてスプレー総量 を $40 \mathrm{ml}$ とし, 基板温度を変化させた場合の, 成長した 酸化スズ膜の XRD プロファイルを Fig. 5 亿示す。基 板温度 $400^{\circ} \mathrm{C}$ では (110) 面, (101) 面, (200) 面书上び (211) 面の低くブロードな回折ピークが認められ，TBT および TBTA の場合とほぼ同様である。基板温度 $450^{\circ} \mathrm{C}$ では TBT とは異なり，(110) 面ではなく(211) 面の回折強度の増大と，(301) 面のプロードで大きな回 折ピークが現れている。また, TBTA とも異なり, （200）面の回折強度の增加は認められない。基板温度 $500^{\circ} \mathrm{C}$ では TBT とは異なり，(110) 面ではなく(101) 面, (200) 面および (301) 面の回折強度の増加が認めら れ, 特に (200) 面のそれは著しい。また, TBTA とあ

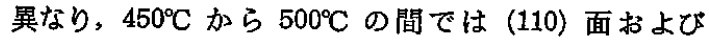
(211) 面の回折ピーク強度の増加は認められない。

TBT, TBTA, DBTDA の 3 種とも膜の結晶化は 400 ${ }^{\circ} \mathrm{C}$ 付近で始まり，温度の上昇に伴ってそれぞれ異なる配 向性を示した。

\subsection{3 $\left(\mathrm{C}_{4} \mathrm{H}_{9}\right)_{3} \mathrm{SnCl}, \mathrm{TBTC}$ およひ $\left(\mathrm{C}_{4} \mathrm{H}_{9}\right)_{2} \mathrm{SnCl}_{2}$, DBTDC}

TBT のブチル基を塩素に置換した有機スズ化合物, TBTC を用いてスプレー総量を $50 \mathrm{ml}$ とし, 基板温度 を変化させた場合の, 成長した酸化スズ膜の XRD プロ ファイルを Fig. 6 に示す。基板温度 $400^{\circ} \mathrm{C}$ では (110) 


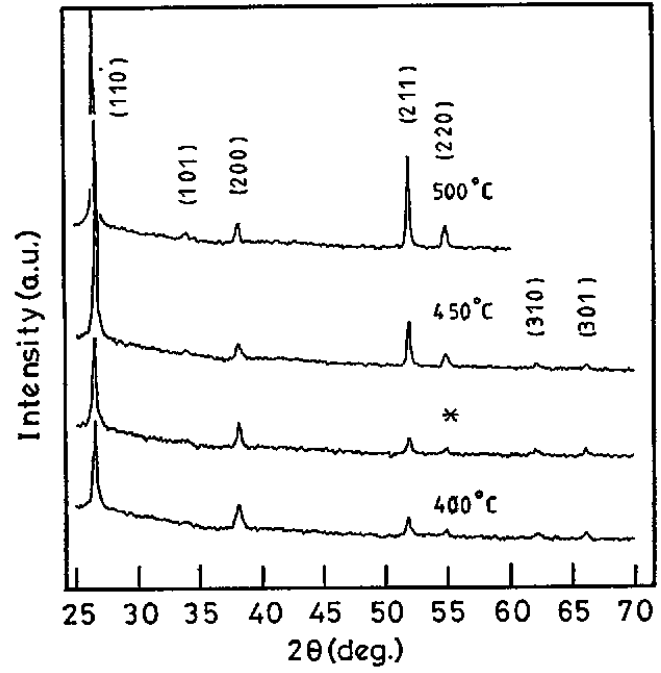

Fig. 6 XRD profiles of $\mathrm{SnO}_{2}$ films grown from $\left(\mathrm{C}_{4} \mathrm{H}_{9}\right)_{3} \mathrm{SnCl}$ solution at various substrate temperatures. *: Annealed at $600^{\circ} \mathrm{C}$ after preared at $400^{\circ} \mathrm{C}$.

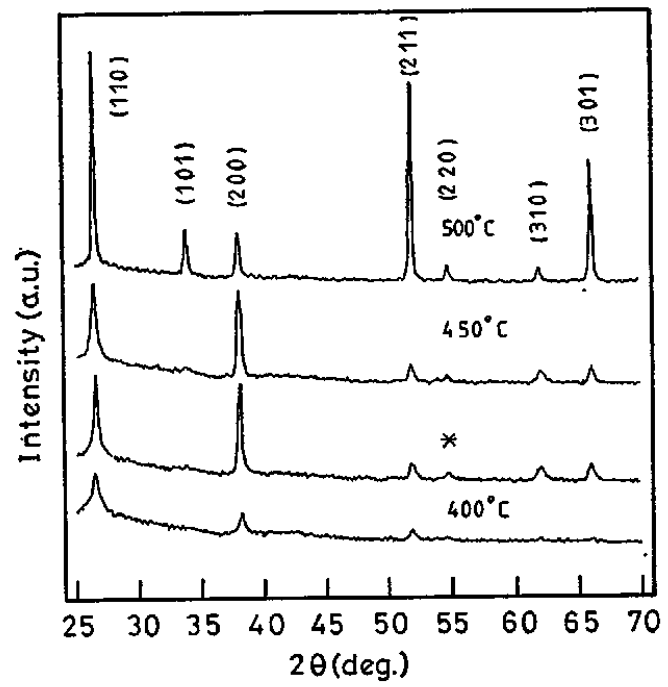

Fig. 7 XRD profiles of $\mathrm{SnO}_{2}$ films grown from $\left(\mathrm{C}_{4} \mathrm{H}_{9}\right)_{2} \mathrm{SnCl}_{2}$ solution at various substrate temperatures. *: Annealed at $600^{\circ} \mathrm{C}$ after prepared at $400^{\circ} \mathrm{C}$.

面の強い回折ピークと (200) 面, (211) 面, (220) 面, (310) 面および (301) 面の弱く，あるいははっきりしな い回折ピークが認められ，TBT と比較すると回折強度 はかなり違うが回折ピークのパターンは TBT の場合と ほほ同様である。基板温度が $450^{\circ} \mathrm{C}, 500^{\circ} \mathrm{C}$ と上昇するに つれ（110）面の回折強度は著しく増加し，また，(211） 面の回折強度もしだいに堌加している。TBT と比較す ると (110) 面の回折強度が增加する点は同じであるが,
(211) 面の回折強度もまた增加する点が巽なっている。 一方，原料化合物に DBTDC を用いてスプレ一総量 を $60 \mathrm{ml}$ とし, 基板温度を変化させた場合の, 成長した 酸化スズ膜の XRD プロファイルを Fig. 7 に示す。基 板温度 $400^{\circ} \mathrm{C}$ では (110) 面, (200) 面および (211) 面の 3つの回折ピークが認められ，TBT の場合とほぼ同様 である。基板温度 $450^{\circ} \mathrm{C}$ では (110) 面之 (200) 面の回折 強度はかなり增加し，新たに (220) 面, (310) 面および (301) 面の回折ピークが認められ，TBT および TBTC と比較すると (200) 面の回折強度が堌加している点で異 なっている。基板温度 $500^{\circ} \mathrm{C}$ では (110) 面, (211) 面お よび (301) 面の回折強度が著しく增加し, 新たに (101) 面の回折ピークが認められるほか，(200）面の回折強度 は減少している。TBT と比較すると(110) 面の回折強 度が増加している点は同じであるが，(211) 面と (301) 面の回折強度る著しく增加し新たに (101) 面の回折ピー クが現れている点で異なっている。

有機スズ化合物を用いた場合, すべて $400^{\circ} \mathrm{C}$ 付近から 結晶化が始まるが, 基板温度 $500^{\circ} \mathrm{C}$ では結晶化の進行と 共に配向性むまた顕著になり，それぞれの原料化合物で 特長のある配向性を示した。

\subsection{4 組織係数による配向性の評価}

XRD プロファイル (Figs. 2 7)の内, 基板温度 $500^{\circ} \mathrm{C}$ のデータを使って求めた組織俰数を Fig. 8 亿示す。原 料化合物に TBT を用いた場合，成長した酸化スズ膜は (110)面および (200) 面に, TBTA では (200) 面および (301)面に, DBTDA では (200) 面および (301) 面に, TBTC では主として (110) 面, (211) 面捄よび (220) 面 に, DBTDC では (301) 面に, TTCでは (200) 面に強 く配向しているととがわかる。(110) 面の強い配向性を 示す原料化合物 TBT のブチル基の一つをアセトキシ基 に置換 (TBTA)すると,(110) 面の配向性は著しく下が り,さらにすう一つ置換 (DBTDA) すると, (110) 面の 配向性は完全に消失している。またその一方で，(200) 面の配向性は強くなり，新たに (301) 面の配向性が現れ てくる。TBT のブチル基の一つを塩素に置換 (TBTC) してむ，(110) 面の配向性はいぜん強く，さらにあう一 つ置換 (DBTDC) しても，乙の配向性は消失しない。ま たこのような置換により TBTC では (211) 面の配向 性がやや強くなり，DBTDCでは (301) 面の強い配向性 が現れ，両者の配向性に違いか諗められる。また，塩素 系有機スズ化合物 (TBTC, DBTDC) の (200) 面の配向 性は, 非塩素系有機スズ化合物 (TBTA, DBTDA) に 比べてかなり弱い。

TTC では (200) 面の強い配向性が認められたが，有 譏スズ化合物を原料として用いた場合にも，より高温に 


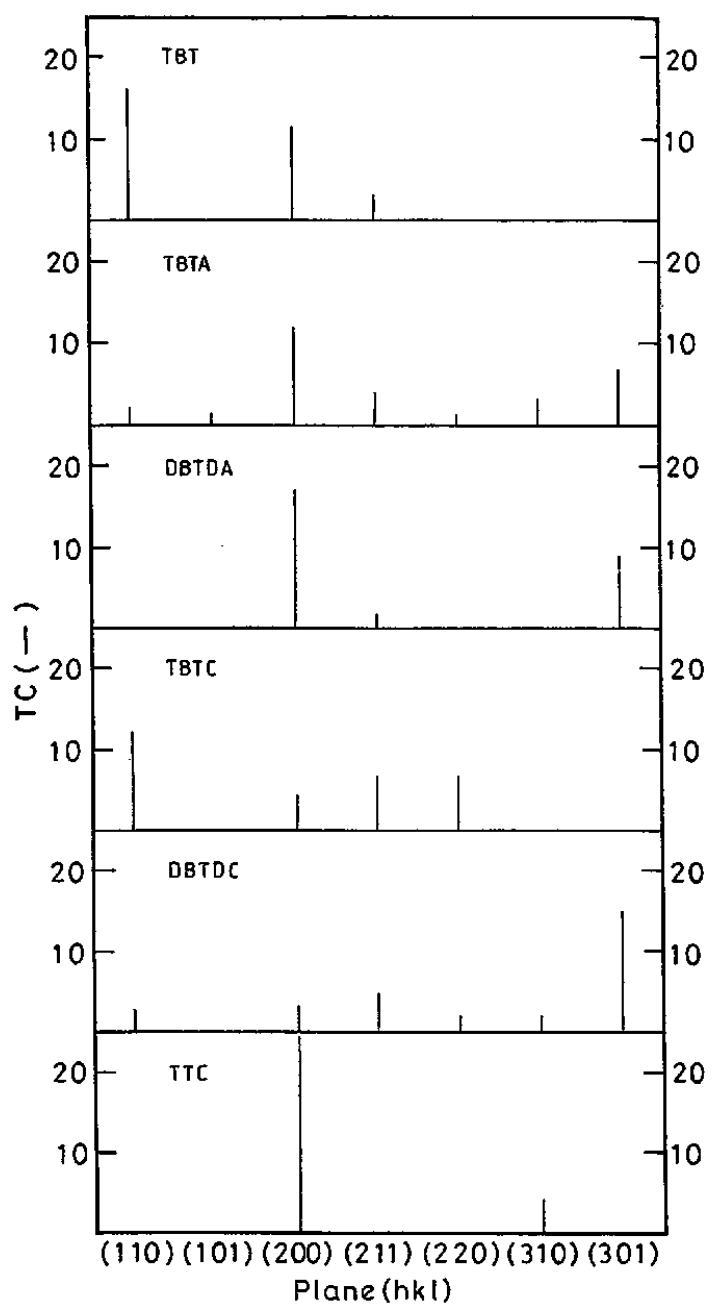

Fig. 8 Texture coefficient of $\mathrm{SnO}_{2}$ films grown from various source compounds at the substrate temperature of $500^{\circ} \mathrm{C}$.

なるとそれぞれ独自の配向性が現れ，興味深い。しかし 原料化合物の分子構造と膜の配向性には一定の関係が認 められず，詳細は今後の検討に待ちたい。

\section{2 アニーリング効果}

それぞれの原料化合物から基板温度 $400^{\circ} \mathrm{C}$ で成長させ た酸化スズ膜を， $600^{\circ} \mathrm{C}$ で 1 時間大気中でアニーリング した後の XRD プロファイルを Figs. 2 7 に示した。 分子中に塩素を含まない TBT, TBTA および DBTDA と塩素を一つ含む TBTC 加ら成長させた酸化スズ膜の アニーリング後の XRD プロファイルはアニーリング前 のそれとまったく変わっていない。

TTC から成長させた酸化スズ膜のアニーリング後の XRD プロファイルには, (110) 面, (101) 面, (200) 面 および (211) 面のブロードな回折ピークが現れた (Fig.
3)。基板温度 $450^{\circ} \mathrm{C}$ で成長させた酸化スズ膜の XRD プ ロファイルと比較すると，ピーク位置は同じすののピー ク高さが異なっている。蛍光X線分析の結果は，アニー リングによる膜中の塩素含有量の減少を示していた。 Chambouleyron らは, 260 490 $\mathrm{C}$ の間では, 反応温度 に対応して, $\mathrm{SnCl}_{4-x}(\mathrm{OH})_{x}$ (ただし, $\left.0<x<4\right)$ のよう に表現できる中間化合物が生成し，塩素が水素とともに 膜中に残留することを示している22)。したがって，ての 場合のアニーリングによる膜の結晶化は，膜中の塩素の 脱離书よび反応中間化合物の分解に伴って進行したもの と考えられる。

アニーリングによって，膜の結晶性に影響が現れた有 機スズ化合物は DBTDC のみであった。すなわち， DBTDC から成長させた酸化スズ膜のアニーリング後 の XRD プロファイルには，(110) 面および (200) 面の 強い回折ピークと (211) 面, (220) 面, (310) 面拈よび (301) 面の弱い回折ピークが認められ, 基板温度 $450^{\circ} \mathrm{C}$ で成長させた酸化スズ膜の XRD プロファイルとほとん ぞ同じである (Fig. 7)。とてであTTC の場合之同様の 原因が考えられるが，営光X線分析によると，膜中の塩 素は当初加ら少なく，アニーリング前後の変化にあそし い。したがって, DBTDC から成長させた酸化スズ膜に アニーリング効果が現れた原因については，塩素含有量 の変化に求めるととができず，いまのととろ明らかでな い。

\section{3 結晶子径およひ配向性}

\subsection{1 スプレー液の総量の影響}

原料化合物に DBTDA を用いて基板温度 $500^{\circ} \mathrm{C}$, ス プレー液濃度 $5.0 \%$, スプレー液供給速度 $1.0 \mathrm{ml} / \mathrm{s}$ とし た場合のスプレー総量と膜厚の関係を Fig. 9 に，また XRD プロファイルから求めた結晶子径を Table 2 にそ れぞれ示す。スプレ一総量と膜厚はほば対応し，膜厚が 増すにつれどの (hkl) 面での結晶子经す滅少する傾向が 現れた。とのととより原料化合物に DBTDA を用いた 場合，膜表面は滑らかであることが予想されるが，SEM 観察の結果は，乙れを慗付けるすのであった [Fig. 10 (a)]。膜厚を $0.2 \sim 0.8 \mu \mathrm{m}$ の間で変化させても，成長 した酸化スズ膜はいずれす (200) 面に強く配向し, 膜厚 が増すにつれて (301) 面の配向も現れた。

一方, 原料化合物化 TTC を用いてスプレー総量（膜 厚）を変化させた場合の，結晶子径を Table 3 亿示す。 TTC の場合は DBTDA の場合之は逆に, 膜厚が增す につれどの (hkl) 面での結晶子径む增大している。これ は膜厚の增大に加えて塩素にも粒成長を促進する効果が あるからと考えられる。との場合, 膜厚の増加とともに粒 成長する傾问があり，また $\mathrm{F} や \mathrm{Sb}$ などのドーピングに 
よっても粒成長する傾向があると報告されている ${ }^{16-18)} 。$ したがって, 原料化合物に TTC を用いて成長させた嬏 化スズ膜の表面は粗いことが予想されるが，SEM 観察

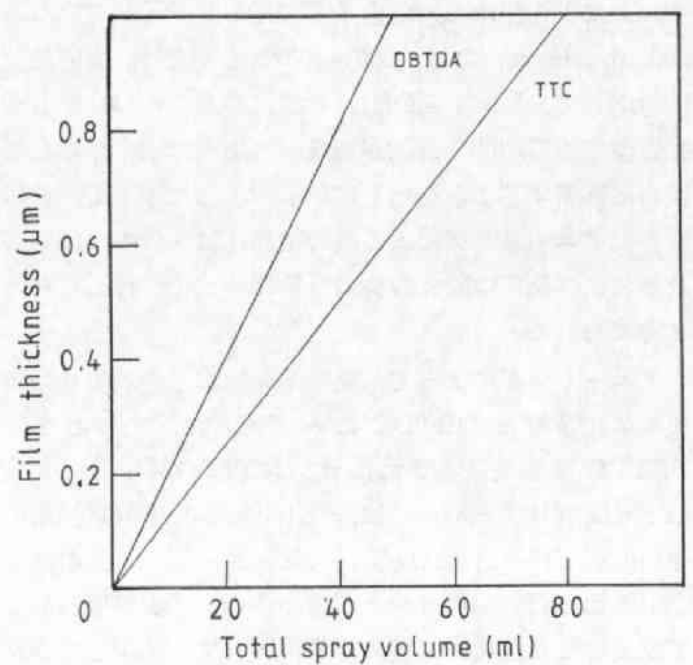

Fig. $9 \mathrm{SnO}_{2}$ film thickness as a function of total spray volume.
の結果はこれを裹付けるあのであった [Fig. $10(\mathrm{~b})$ ]。 膜厚を $0.125 \sim 0.5 \mu \mathrm{m}$ と变化させてす, 成長した酸化 スズ膜は (200) 面に強く配向し，この点は DBTDA と 類似していた。基板にソーダライムガラスを用いた場合

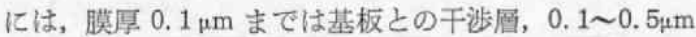
には無配向層が形成され，配向成長は $0.5 \mu \mathrm{m}$ 以上の膜 厚で観察されるとの報告があるが ${ }^{12)}$ ，基板にコーニング 7059 ガラスなどを使用した場合は，膜厚 $0.08 \mu \mathrm{m}$ であ (200) 面の配向成長か3観察されている゙11。

\section{2 .2 スプレー液の供給速度の影寣}

原料化合物に DBTDA を用いて基板温度 $500^{\circ} \mathrm{C}$, ス プレー濃度 $5.0 \%$ ，スプレー総量 $20 \mathrm{ml}$ としスプレー供 給速度を変化させた場合の成長した酸化スズ膜の XRD プロファイルより求めた組織係数を Fig. 11 に，また結 晶子径を Table 4 にそれぞれ示す。スプレー液供給速 度を $0.5 \sim 1.5 \mathrm{ml} / \mathrm{s}$ と変化させても, 成長した酸化スス 膜は (200) 面に配向し，スプレー液供給速度が小さくな るほど (200) 面に強く配向している。スプレー液供給速 度が $0.51 \mathrm{ml} / \mathrm{s}$ の場合の (200) 面での結晶子径は他の面 の結晶子径に比へてかなり大きい。とれは (200) 面が優

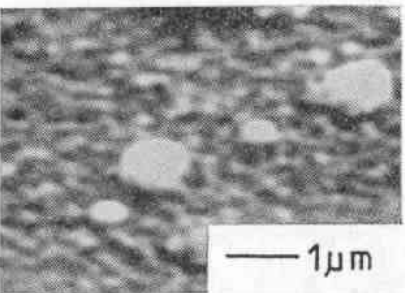

(b) TTC

Fig. 10 SEM images of surface morphology of $\mathrm{SnO}_{2}$ films grown from (a) DBTDA and (b) TTC.

Table 2 Crystallite size of $\mathrm{SnO}_{2}$ grown from $\left(\mathrm{C}_{4} \mathrm{H}_{9}\right)_{2} \mathrm{Sn}\left(\mathrm{OOCCH}_{3}\right)_{2}$ solution of various total spray volumes.

\begin{tabular}{|c|c|c|c|c|c|c|c|}
\hline $\begin{array}{l}\text { Total spray volume } \\
\qquad(\mathrm{ml})\end{array}$ & (110) & $\begin{array}{l}\text { Crys } \\
(101)\end{array}$ & $\begin{array}{l}\text { allite } \\
(200)\end{array}$ & $\begin{array}{l}\text { ize (nm } \\
(211)\end{array}$ & $\begin{array}{l}\text { /Plane } \\
(220)\end{array}$ & $\begin{array}{l}(\mathrm{hkl}) \\
(310)\end{array}$ & (301) \\
\hline 10 & & & 19 & 21 & & & 18 \\
\hline 20 & & 7 & 18 & 22 & & & 14 \\
\hline 40 & & 7 & 17 & 19 & & & 14 \\
\hline
\end{tabular}

Table 3 Crystallite size of $\mathrm{SnO}_{2}$ grown from $\mathrm{SnCl}_{4}$ solution of various total spray volumes.

\begin{tabular}{|c|c|c|c|c|c|c|c|}
\hline $\begin{array}{l}\text { Total spray volume } \\
(\mathrm{ml})\end{array}$ & (110) & $\begin{array}{l}\text { Crys } \\
(101)\end{array}$ & $\begin{array}{l}\text { allite : } \\
(200)\end{array}$ & $\begin{array}{l}\text { ize (nm } \\
(211)\end{array}$ & $\begin{array}{l}\text { /Plane } \\
(220)\end{array}$ & $\begin{array}{l}(\mathrm{hkl}) \\
(310)\end{array}$ & (301) \\
\hline 10 & & & 22 & & & 12 & \\
\hline 20 & 8 & & 24 & & & 17 & 16 \\
\hline 40 & & & 27 & & & 21 & 25 \\
\hline
\end{tabular}


先的に成長するため他の面の成長が妨げられるからであ ると考えられる。

\subsection{3 スプレー夜の湦度の影每}

原料化合物化 DBTDA を用いて基板温度 $500^{\circ} \mathrm{C}$, ス プレー液供給速度 $1.0 \mathrm{ml} / \mathrm{s}$, スプレー濃度を変化させた 場合の成長した酸化スズ膜の XRD プロフェイルより求 めた結晶子径を Table 5 亿示す。結晶子径はスプレー 液濃度の減少に伴って增大傾向にある。乙れはスプレー 液の濃度の減少により, 膜の成長速度が遅くなったから であると考えられる。また, 配向性については, スプレ 一液の濃度を $2.0 \sim 10 \%$ と変化させても, 成長した酸化
スズ膜は強く(200) 面に配向した。

\subsection{SEM 観察}

原料化合物 TBT および DBTDC から基板温度 500 ${ }^{\circ} \mathrm{C}$, スプレー供給速度約 $1.0 \mathrm{ml} / \mathrm{s}$, スプレー液濃度 2.0 \% で成長させた酸化スズ膜の SEM 像をそれぞれ Fig. 12 (a) と（b) に示した。分子中に塩素を含まない原料 化合物 TBT を用いて成長させた酸化スズ膜の表面は 滑らかである。一方, 分子中に塩素を含む原料化合物 DBTDC を用いて成長させた酸化スズの表面は荒く，粒 子径は約 $0.2 \mu \mathrm{m}$ で表面に大きな粉体粒子が付着してい る。3.3.1 で示した DBTDA および TTC の SEM 写

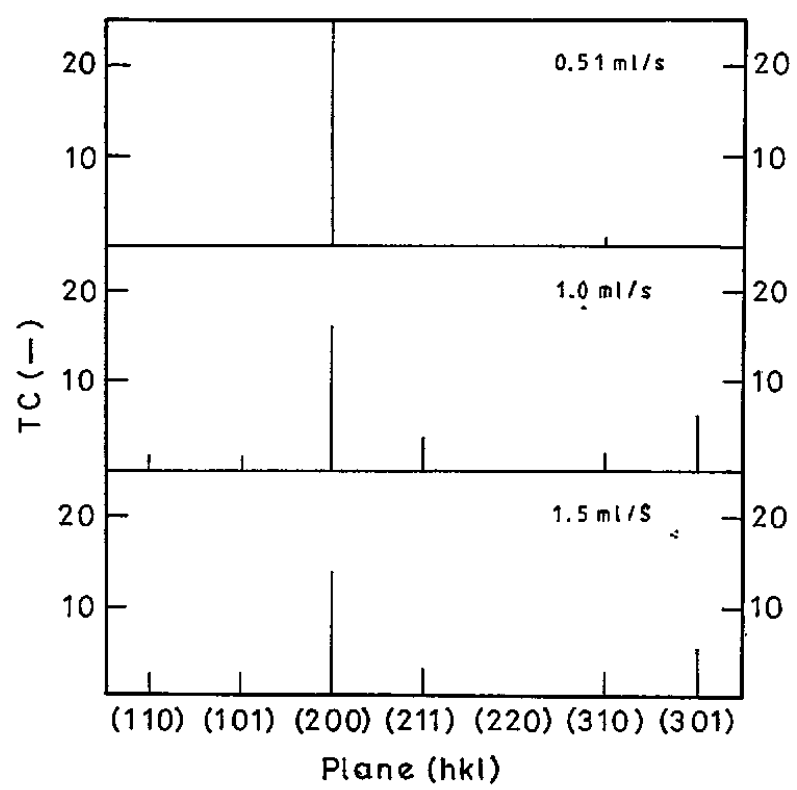

Fig. 11 Texture coefficient of $\mathrm{SnO}_{2}$ films grown from $\left(\mathrm{C}_{4} \mathrm{H}_{9}\right)_{2} \mathrm{Sn}\left(\mathrm{OOCCH}_{3}\right)_{2}$ solution at various spray rates.

Table 4 Crystallite size of $\mathrm{SnO}_{2}$ grown from $\left(\mathrm{C}_{4} \mathrm{H}_{9}\right)_{2} \mathrm{Sn}\left(\mathrm{OOCCH}_{3}\right)_{2}$ solution at various spray rates.

\begin{tabular}{c|ccccccc}
\hline $\begin{array}{c}\text { Spray rate } \\
(\mathrm{ml} / \mathrm{s})\end{array}$ & $(110)$ & $(101)$ & $(200)$ & $(211)$ & $(220)$ & $(310)$ & $(301)$ \\
\hline 0.51 & & & 22 & & & 13 & \\
1.0 & & 7 & 18 & 22 & & & 14 \\
1.5 & & 11 & 20 & 23 & 17 & 20 \\
\hline
\end{tabular}

Table 5 Crystallite size of $\mathrm{SnO}_{2}$ grown from $\left(\mathrm{C}_{4} \mathrm{H}_{9}\right)_{2} \mathrm{Sn}\left(\mathrm{OOCCH}_{3}\right)_{2}$ solution of various concentrations.

\begin{tabular}{c|ccccccc}
\hline \multirow{2}{*}{$\begin{array}{c}\text { Concentration } \\
\text { (wt \%) }\end{array}$} & \multicolumn{5}{|c}{ Crystallite size (nm)/Plane (hkl) } \\
\hline 2.0 & & & 24 & 20 & & 21 & 17 \\
5.0 & & 7 & 18 & 22 & & 14 \\
10 & & & 18 & 18 & & 10 & 10 \\
\hline
\end{tabular}




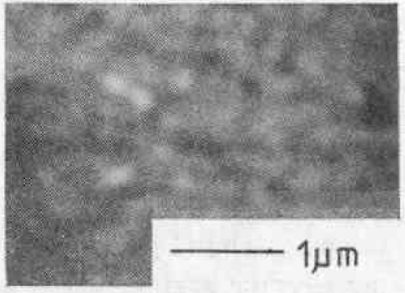

(a) TBT

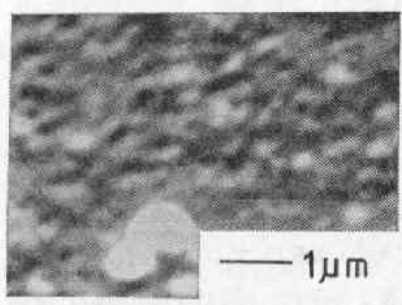

(b) DBTDC

Fig. 12 SEM images of surface morphology of $\mathrm{SnO}_{2}$ films grown from (a) TBT and (b) DBTDC.

真 (Fig. 10) の結果と考え合わせると, 分子中に塩素を 含む原料化合物では粒成長が起とりやすく粒子が大きく なり，表面か粗くなると考えられる。一方分子中に塩素 を合まない原料化合物ではそのような効果か起こらず, 表面が比較的滑らかになったと考えられる。

\section{4. ま と め}

原料化合物に注目してスプレー热分解法による酸化ス ズ膜の成長を試みた。従来,一般的に用いられてきた $\mathrm{SnCl}_{4}$ に対して, 中心金属 $\mathrm{Sn}$ への置換基の種類と数を 順次変えた一連の有機スズ化合物 $\left[\mathrm{Sn}\left(\mathrm{C}_{4} \mathrm{H}_{9}\right)_{4}, \quad\left(\mathrm{C}_{4} \mathrm{H}_{9}\right)_{3}\right.$ $\mathrm{SnOOCCH}_{3},\left(\mathrm{C}_{4} \mathrm{H}_{9}\right)_{2} \mathrm{Sn}\left(\mathrm{OOCCH}_{3}\right)_{2},\left(\mathrm{C}_{4} \mathrm{H}_{9}\right)_{3} \mathrm{SnCl}$ および $\left(\mathrm{C}_{4} \mathrm{H}_{9}\right)_{2} \mathrm{SnCl}_{2}$ ] を用い, 膜の成長条件と微構造を検討し, つぎのととを明らかにした。

（1）有機スズ化合物を用いた場合，膜の結晶化は約 $400^{\circ} \mathrm{C}$ 加ら始まり, 基板温度の上昇とともに, それ ぞれの原料化合物に特有の配向性か現れた。

（2）勘板温度 $500^{\circ} \mathrm{C}$ で成長させた酸化スズ膜の配 向性は, それぞれの原料化合物に強く恢存し, $\mathrm{Sn}$ $\left(\mathrm{C}_{4} \mathrm{H}_{9}\right)_{4}$ では (110) 面尔よび (200) 面の, $\left(\mathrm{C}_{4} \mathrm{H}_{9}\right)_{3} \mathrm{Sn}$ $\mathrm{OOCCH}_{3}$ では (200) 面求よひ (301) 面の, $\left(\mathrm{C}_{4} \mathrm{H}_{9}\right)_{2}$ $\mathrm{Sn}\left(\mathrm{OOCCH}_{3}\right)_{2}$ では (200) 面の, $\left(\mathrm{C}_{4} \mathrm{H}_{9}\right)_{3} \mathrm{SnCl}$ では (110) 面, (211) 面书よび (220) 面の, $\left(\mathrm{C}_{4} \mathrm{H}_{9}\right)_{2} \mathrm{SnCl}_{2}$ では (301) 面のいずれも強い配向性を示した。

(3) 分子中に塩素を二つ合む DBTDC では, 膜の 成長に関するアニーリング効果が㥨められた。

（4）分子中にアセトキシ基を二つ含む DBTDA か ら成長させた酸化スズ膜の結晶子经は，それぞれ膜 厚の増大ととあに小さくなり, スプレー液供給速度 の減少およびスプレー波濃度の低下とともに大きく なった。

（5）塩素を含まない原料化合物から成長させた膜の 表面は比䡐的滑らかになる傾向があった。

\section{文献}

1) Z. M. Jarzebski and J.P. Marton: J. Electrochem. Soc. 123, 199C (1976).
2) A. L. Dawar and J. C. Joshi : J. Mater. Sci. 19, 1 (1984).

3) J. M. Mochel : U.S. Pats. 2564706, 2564707, 2564708, 2564710 and 2564987 (1951).

4) R.R. Chamberlin and J.S. Skarman : J. Electrochem. Soc. 113, 86 (1966).

5) J. B. Mooney and S. B. Radding: Ann. Rev. Mater. Sci. [12] 81 (1982).

6) H. Kim and H. A. Laitinen: J. Amer. Ceram. Soc. 58, 23 (1975).

7) H. Pink, L. Treitinger and L. Vite: Jpn. J. Appl. Phys. 19, 513 (1980).

8) H. Haitjema and J. Elich : Sol. Energy Mater. 16. 79 (1987).

9) J.J. Ph. Elich, E.C. Boslooper and H. Haitjema ; Thin Solid Films 177, 17 (1989).

10) C. Agashe, M. G. Takwale, B.R. Marathe and V. G. Bhide: Sol. Energy Mater. 17, 99 (1988).

11) M Fujimoto, Y. Nishi, A. Ito, T. Mishuku, H. Iida and S. Shirasaki: Jpn. J. Appl. Phys. 27, 534 (1988).

12) M. Fujimoto, T. Urano, S. Murai and Y. Nish: Jpn. J. Appl. Phys. 28, 2587 (1989).

13) C. Barret and T. B. Massalski : Structure of Metals (Pergamon, Oxford, 1980) p. 204.

14）仁田 勇： X線結晶学下 (丸普(株), 1961) p. 512.

15) H Iida, T. Mishuku, A. Ito, K. Kato, M. Yamanaka, and Y. Hayashi : Sol. Energy Mater. 17, 407 (1988).

16) E. Shanthi, V. Dutta, A. Banerjee and K. L. Chopra: J. Appl. Phys. 51, 6243 (1980).

17) H. Haitjema, J. J. Ph. Elich and C. J. Hoogendoorn : Sol. Energy Mater. 18, 283 (1989).

18) M. Fantini and I. Torriani : Thin Solid Films 138, 255 (1986).

19) J. Sanz Maudes and T. Rodriguez: Thin Solid Films 69, 183 (1980).

20) J.C. Manifacier, J.P. Fillard and J. M. Bind: Thin Solid Films, 77, 67 (1981).

21) J. Melsheimer and B. Tesche : Thin Solid Films 138, 71 (1986).

22) J. Chambouleyron, C. Constantino, M. Fantini and M. Farias: Sol. Energy Mater. 9, 127 (1983). 